\title{
Melden van bijwerkingen
}

Hoewel geneesmiddelen en vaccins jarenlang worden onderzocht voordat ze op de markt komen en gebruikt worden, komen in de praktijk toch soms nieuwe bijwerkingen aan het licht. Het is van belang bijwerkingen te melden bij het Nederlands Bijwerkingen Centrum Lareb. Door alle meldingen op één centraal punt te verzamelen, kan Lareb de veiligheid van geneesmiddelen en vaccins in Nederland bewaken. Lareb verzamelt en analyseert per jaar ruim 11.000 meldingen. Artsen en apothekers zijn volgens de Geneesmiddelenwet verplicht ernstige bijwerkingen te melden bij Lareb. Onder 'ernstige bijwerkingen' verstaat men:

- bijwerkingen die leiden tot een ziekenhuisopname of verlenging hiervan,

- aangeboren afwijkingen,

- arbeidsongeschiktheid, invaliditeit,

- levensbedreigende situatie of overlijden.

Naast ernstige bijwerkingen, is Lareb ook geïnteresseerd in:

- onbekende bijwerkingen (bijwerkingen die niet in de bijsluitertekst staan opgenomen);

- bijwerkingen van nieuwe geneesmiddelen;

- bijwerkingen bij kinderen.

Melden van bijwerking kan via het meldformulier op ww.lareb.nl

\section{Geneesmiddelen en zwangerschap}

Bij de Teratologie Informatie Service (TIS) van Lareb kunnen zorgverleners terecht voor vragen over risico's van geneesmiddelen rond vruchtbaarheid, zwangerschap en borstvoeding. TIS is tijdens kantooruren dagelijks te bereiken op $073-6469702$.

Informatie over geneesmiddelengebruik en zwangerschap is ook te vinden op de website van Lareb (www.lareb.nl). 